\title{
Effect of Green Manure Amendments and Spray of Spices Extract on Purple Blotch Disease Intensity of Onion (Allium cepa L)
}

\author{
B. V. Rama Krishnam Raju* and Sobita Simon \\ Department of Plant Pathology, Sam Higginbottom University of Agriculture, Technology and \\ Sciences, Prayagraj, U. P, India \\ *Corresponding author
}

\begin{abstract}
A B S T R A C T
Keywords

Onion, Alternaria porri, Purple blotch, Carbendazim, Green manure, Spices

Article Info

Accepted:

14 November 2020

Available Online:

10 December 2020

A field experiment was conducted at the research plot of the Department of Plant pathology, SHUATS, Prayagraj, U.P. during the rabi season of 2018-19 to observe the practices for Effect of green manure amendments and spray of spices extract on purple blotch disease of onion (Alliumcepa L). A survey was conducted during Rabi season 2018 in Prayagraj district of U.P. Maximum disease severity was noticed at Champatpur village $(48.33 \%)$ and minimum disease severity was noticed Piparsa $(25.66 \%)$ in Prayagraj district. A total of seven spices treatments namely Black cumin, Bay Leave, Ajowan, Neem, Tobacco, and Carbendazim including control (green manure) were replicated three times. Results showed that among all the treatments, carbendazim 50\%WP @ 1500g/ha (20.67\%) was most effective treatment in reducing purple blotch intensity in field condition. The spice extracts were evaluated at $10 \%$ concentration in the laboratory for their efficacy against the A. Porri by following Poisoned food technique. Among the five spices tested, all the spices showed inhibition of A. porri at varied level. Maximum inhibition was shown by tobacco (41.67\%) and minimum by Ajowan (34.60\%).
\end{abstract}

\section{Introduction}

Onion (Allium cepa L.) a member of family Liliaceae is a vegetable crop of global importance and is known as protective food because of its special nutritive and medicinal value. It owns potent medicinal value in ayurvedic and homoeopathic therapy. It is also regarded as an anticancer source of food. Allyl-propyl-di-sulphide is the main ingredient responsible for pungency in bulbs, which help to prevent cancer. Among the vegetables, onion often called as "queen of kitchen" (Selvaraj, 1976). Is one of the oldest known vegetable grown in India. It is commonly used for cooking purposes by all the community of people. It ensures excellent taste to dishes and also exhibits a number of therapeutic properties such anti-bacterial, antifungal, antihelmintic, anti-inflammatory, antiseptic, antispasmodic, etc. Onion is one of the potential foreign exchange earners for a country like India, as it is second largest producer of onions after China. It contributes $19.25 \%$ of total world production (FAO, 2012). Though India ranks first in terms of the area under onion cultivation in the world and second in its production. It is one of the 
important ingredients of the daily diet facilitating a constant year round consumer demand. The productivity is still quite low as compared to other countries Anonymous, (2015). Onion crop is attacked by bacteria, fungi, nematodes, viruses, phytoplasma, phanerogamic plant parasite and many other miscellaneous diseases and disorder. Among these diseases, the purple blotch (A. porri) is one of the major constrains in onion cultivation. The pathogen is polyphagus infecting crop like onion, garlic, shallot and other Allium crops (Sandhu et.al., 1981).

\section{Materials and Methods}

The green manure evaluated under field condition. Field experiments were laid-out in Randomized block design with three replications at research plot of the department of Plant Protection, Sam Higginbottom University of Agriculture Technology and Sciences, during the Rabi season of 2018-19 and used in green manure were given at an before sowing. Treatments were imposed after appearance of the first disease symptoms. Observations on disease severity of purple blotch of onion were recorded at 15 days interval and yield data were obtained after the harvest on physiological maturity (Abdullahi et al., 2009) (Table 1).

\section{Collection of Disease sample}

Leaves were collected in a clean polythene bag and brought to the laboratory from infected onion plant having characteristic symptoms of disease (Plate 3.2).

\section{Examination of samples in the laboratory}

The organisms were examined after collection from the field. Any microorganism associated with disease, morphological features were examined under a compound microscope. Preliminary examination was carried out with water mounts of scrapings from the infected tissue. After placing the specimens in the centre of the drop of mounting, it was covered with a correct sized cover slip using a tip of dissecting needle to press it down. The excess fluid bloated out and the cover slip sealed with quick fix. The temporary mounts and permanent slide thus prepared may be examined under the microscope to know the morphological feature of microorganism.

\section{Isolation and Purification of Pathogen}

Small pieces of tissues about $3 \mathrm{~mm}$ from infected collar region with some healthy tissue where cut with sterile scalpel. Then the pieces surface sterilized with one percent sodium hypochlorite solution for $30 \mathrm{sec}$. The tissue pieces were subsequently washed in three changes of sterile distilled water to eliminate excess sodium hypochlorite and then pieces were transferred to PDA plated petri dishes in presence of laminor air flow chamber. plates were incubated at $28 \pm 2{ }^{\circ} \mathrm{C}$ and were observed periodically for growth of the fungus.

\section{Identification of Alternaria porri}

Examination of the fungal colony characteristics were done through microscopic examination. Using a sterile needle, a small portion of the culture is taken and placed on a sterile glass slide. It is stained using lactophenol and cotton blue. Then, the microscope is used for the examination of morphology and culture characteristics of fungal structures.

\section{Characteristics of Alternaria porri (Elli)}

The conidia of $A$. porri as obclavate, borne singly on the tip of conidiophores, rarely in chains. The main body of the conidium was brown, transversely as well as longitudinally septate, number of transverse septa varied in 
the range of 10-12. The beak was sub-hyaline, simple or forked. The sizes of conidia from stem and leaf lesion ranged from $105 \mu \mathrm{x}$ $220.5 \mu, 17.5 \mu \times 26.0 \mu$ and on artificial media (onion agar medium) $140 \mu \times 370 \mu$ by $14.5 \mu \mathrm{x}$ 33.0 $\mu$, respectively (Rands, 1917).

\section{Symptoms of purple blotchononion}

Change in colour of leaves was started from centre of the lesion which extended above and below the lesion further the lesion coalesce and spread rapidly on leaf blade and effected leaves showed drying. The symptoms were characteristic to that of purple blotch disease caused by Alternaria porri. The morphological study of the fungus was carried out on PDA. The white colonies turned into purple color with advancing age of culture.

The observations were recorded on sevendays-old culture for the characters of the colony, mycelium, conidiophores and conidia and later their comparison with the characteristics described in the available literature (Barnett and Hunter, 1987; Singh, 1992).

Disease intensity- according to singh et al (1982) scale given on scale 0-9 scales was used to record disease intensity.

Disease intensity (\%) was calculated by using the following formula:

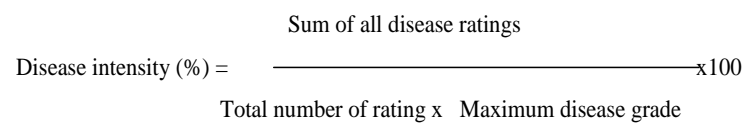

\section{Poisoned food technique}

Five $\mathrm{mm}$ diameter of culture disc of Alternaria porri was kept at the centre of each petri plate containing the fungicides of required concentration dissolved in PDA. Three replications were maintained . The plates were incubated at $27{ }^{\circ} \mathrm{C}$ for ten days and colony diameter was recorded. Per cent inhibition of mycelial growth was calculated by using the formula given by Vincent (1947).

$I=\frac{(C-T)}{C} \times 100$

Where

$\mathrm{C}=$ Radial growth in control.

$\mathrm{T}=$ Radial growth in treatment.

\section{Preparation of Plant extracts}

Leaves were collected from the tree the leaves were weighed in an electric balance and then washed in the water. After washing, the big leaves were cut into small pieces. For getting extract, weighed plant parts were blended in an electric blender and distilled water was added into the blender.

The pulverized mass was squeezed through 3 folds of fine cotton cloth. Forgetting 1:2(w/v) ratio $200 \mathrm{ml}$ of distilled water was added to $100 \mathrm{~g}$ plant parts.

The extracts of the botanicals was used for the experiment in the field condition as well as in vitro experiment. Ten $\mathrm{ml}$ of leaf extracts was mixed with $100 \mathrm{ml}$ of water and sprayed on plants. In the lab experiment $10 \%$ of leaf extract was added into $90 \mathrm{ml}$ of PDA. The flasks were kept in the auto clave for sterilization before using for the in vitro (poisoned food technique) experiments.

\section{Methods}

A survey was carried out during Rabi 2018 on onion crop during crop season to record the occurrence and distribution of purple blotch. Random survey was carried out in ten villages of Allahabad district viz., champatpur, 
Piparsa, Muradpur, Khama chakiya, Balsarag, Barali, Khitaria, Takari, Pahvri, Panvar five farmer's field were selected in each village with plot size $\left(10^{2} \mathrm{~m}\right)$. diseased samples were collected from each plot for isolation and identification of purple blotch incidence (Vinny John, 2018).

\section{Results and Discussion}

The systematic survey was conducted in 10 onion growing villages of Allahabad district during rabi season of 2018. The disease was prevalent at all the locations surveyed and the purple blotch disease incidence varied from minimum Muradpur (25.66\%) to maximum Champatpur (48.33\%).
The highest followed by Piparsa (38.33\%), Khamachakiya (43.33\%), balsarg (39.99), Barali (33.33\%), Khitariya (39.99\%), Takari (34.99\%), Pahvri (43.33\%), Panvar (39.99\%). respectively shown in the Table 2 . Identification of morphological and pathogenic $A$. porri showed that purple blotch is present in maximum plots surveyed in the villages of Allahabad. The infected leaves were observed for purple blotch symptoms. The development of the initial symptoms starts from tip of the leaves particularly on older leaves and then spread to young leaves. Infected leaves showed small, whitish, sunken, oval shaped lesions to elliptical. The lesion was brown to purple at the centre. Concentric light and dark zones are also observed on the infected leaves.

The scale for disease assessment was as follows

\begin{tabular}{|c|c|c|}
\hline Sl. No. & Percent leaf area covered & Grade $(\mathbf{x})$ \\
\hline 1. & 0 & $\mathbf{0}$ \\
\hline 2. & 1 & $\mathbf{1}$ \\
\hline 3. & $2-10$ & $\mathbf{3}$ \\
\hline 4. & $11-25$ & $\mathbf{5}$ \\
\hline 5. & $26-50$ & $\mathbf{7}$ \\
\hline 6. & $\mathbf{5 0}>$ & $\mathbf{9}$ \\
\hline
\end{tabular}

1. No disease symptoms.

2. A few spots towards tip covering 10 per cent leaf area.

3. Several dark purplish brown patch covering upto 20 per cent leaf area.

4. Several patches with paler outer zone covering upto 40 per cent leaf area.

5. Leaf streaks covering upto 75 per cent leaf area or breaking of the leaves from center.

6. Complete drying of the leaves or breaking of the leaves from center
The data presented in table 3 and depicted in figure $1 \mathrm{~b}$ at 60 DAT shows that all the treatment of green manure and spray spice extract significantly reduced Alternaria porri disease intensity (\%) on compared the percentage inhibition of Alternaria porri were found in control compared $\mathrm{T}_{0^{-}}$(36.87) with $\mathrm{T}_{3}$-Ajowan (23.22) significantly reduce in incidence $\%$ an compared with $\mathrm{T}_{2}$ - Bay Leave (27.30), $\mathrm{T}_{1}$-Black cumin (25.32), $\mathrm{T}_{4}$-Neem (24.45), $\mathrm{T}_{5}$-Tobacco (24.27), Among the treatments $\left(\mathrm{T}_{2}, \mathrm{~T}_{1}\right)$ and $\left(\mathrm{T}_{1}, \mathrm{~T}_{4}, \mathrm{~T}_{5}, \mathrm{~T}_{3}\right)\left(\mathrm{T}_{5}, \mathrm{~T}_{3}\right.$, were found non-significant from one another

The minimum percentage of disease intensity was observed in $\mathrm{T}_{6}$ (carbendazim).the probable reasons for such findings may be the 
suppressive ability of carbendazim in inhibiting growth of the soil borne pathogens has been demonstrated to be through competition, antibiosis or due to increase of soil microbial populations. Similar findings is report by (akash verma, and sobita simon 2013.) observed that carbendazim proved to be most effective against Alternaria lini showed minimum percentage of disease intensity.

\section{6 hrs Mycelial growth of Alternaria porri}

The data presented in table 4 and depicted in figure 2 reveals the response on evaluation of effect of spice extract at $10 \%$ on radial growth of Alternaria porri at 96 hrs in under lab condition. Among the treatments significantly reduced of Alternaria porri was Compared with control. The treatments were $\mathrm{T}_{3}$-Ajowan (34.50) followed by $\mathrm{T}_{1}$-Black cumin (36.83), $\mathrm{T}_{2}$-Bay Leave (37.83), $\mathrm{T}_{4-}$ Neem (39.0), $\mathrm{T}_{5}$-Tobacco (41.67) are not significantly differ the radial growth of Alternariaporri but they are significantly reduced from $\mathrm{T}_{0}$ (Control-12.74). The treatments are $\left(\mathrm{T}_{3}, \mathrm{~T}_{1}, \mathrm{~T}_{2}, \mathrm{~T}_{4}\right) \quad\left(\mathrm{T}_{1}, \mathrm{~T}_{2}, \mathrm{~T}_{4}, \mathrm{~T}_{5}\right)$ significantly reduce the percentage of radial growth of Alternaria porri than $\mathrm{T}_{0}$. Where as the treatments are $\left(\mathrm{T}_{3}, \mathrm{~T}_{1}, \mathrm{~T}_{2}, \mathrm{~T}_{4}\right)\left(\mathrm{T}_{1}, \mathrm{~T}_{2}, \mathrm{~T}_{4}, \mathrm{~T}_{5}\right)$ and $\left(\mathrm{T}_{0}, \mathrm{~T}_{3}\right)$ non significant from each other.

Table.1 Details of treatment

\begin{tabular}{|c|l|l|}
\hline S.No. & Treatments & Doses \\
\hline $\mathbf{T}_{\mathbf{0}}$ & Control & \\
\hline $\mathbf{T}_{\mathbf{1}}$ & Green manure + Black Cumin ( seeds) & $@ 10 \%$ \\
\hline $\mathbf{T}_{\mathbf{2}}$ & Green manure + Bay Leave (Tejpatt Leaves) & $@ 10 \%$ \\
\hline $\mathbf{T}_{\mathbf{3}}$ & Green manure + Ajwain (seeds) & $@ 10 \%$ \\
\hline $\mathbf{T}_{\mathbf{4}}$ & Green manure + Neem (Leaves) & $@ 10 \%$ \\
\hline $\mathbf{T}_{\mathbf{5}}$ & Green manure + Dry Tobacco (Leaves) & $@ 10 \%$ \\
\hline $\mathbf{T}_{\mathbf{6}}$ & Green manure + Carbendazim & $@ 2 \mathrm{~g} / \mathrm{lt}$ \\
\hline
\end{tabular}

Table.2 Survey of Disease intensity (\%) of purple blotch of onion from different villages in Prayag raj district 2018-2019

\begin{tabular}{|c|c|c|c|c|c|c|c|c|}
\hline \multirow{2}{*}{$\begin{array}{l}\text { Name of } \\
\text { villages }\end{array}$} & \multirow{2}{*}{$\begin{array}{l}\text { No. of field } \\
\text { surveyed }\end{array}$} & \multirow{2}{*}{$\begin{array}{l}\text { No. of } \\
\text { diseased } \\
\text { plant in } \\
\text { each field }\end{array}$} & \multicolumn{5}{|c|}{ No. of infected area $\left(10^{2} \mathrm{~m}\right)$ in surveyed fields } & \multirow{2}{*}{$\begin{array}{c}\text { Blotch } \\
\text { incidence }(\%)\end{array}$} \\
\hline & & & F1 & $\mathbf{F} 2$ & F3 & $\mathbf{F 4}$ & F5 & \\
\hline Champatpur & 5 & 5 & 25 & 100 & 50 & 33.33 & 33.33 & 48.33 \\
\hline piparsa & 5 & 5 & 25 & 50 & 33.33 & 50 & 33.33 & 38.33 \\
\hline Muradpur & 5 & 5 & 33.33 & 20 & 33.33 & 16.66 & 25 & 25.66 \\
\hline Karmachakiya & 5 & 5 & 33.33 & 100 & 25 & 25 & 33.33 & 43.33 \\
\hline Balsarag & 5 & 5 & 33.33 & 50 & 50 & 33.33 & 33.33 & 39.99 \\
\hline Barali & 5 & 5 & 33.33 & 33.33 & 33.33 & 33.33 & 33.33 & 33.33 \\
\hline Khitariya & 5 & 5 & 50 & 33.33 & 33.33 & 50 & 33.33 & 39.99 \\
\hline Tikari & 5 & 5 & 33.33 & 50 & 25 & 33.33 & 33.33 & 34.99 \\
\hline Panvari & 5 & 5 & 33.33 & 50 & 33.33 & 50 & 50 & 43.33 \\
\hline Pahvar & 5 & 5 & 50 & 33.33 & 33.33 & 50 & 33.33 & 39.99 \\
\hline
\end{tabular}


Table.3 Effect of green manure amendments and spray of spice extract on purple blotch disease intensity $(\%)$ of onion at 45 and 60 DAT

\begin{tabular}{|c|c|c|c|c|c|}
\hline S.No & Treatments & $\begin{array}{l}45 \text { DAT }(\%) \\
\text { P.D.I }\end{array}$ & $\begin{array}{c}(\%) \text { reduction } \\
\text { over control }\end{array}$ & $\begin{array}{l}\text { 60 DATS } \\
\text { (\%) P.D.I }\end{array}$ & $\begin{array}{c}(\%) \text { reduction } \\
\text { over control }\end{array}$ \\
\hline T0 & Control & 22.04 & & 36.87 & \\
\hline $\mathrm{T} 1$ & $\begin{array}{l}\text { Green Manure+Black } \\
\text { cumin }\end{array}$ & 18.98 & 13.88 & 25.32 & 31.32 \\
\hline $\mathrm{T} 2$ & Green Manure+Bay leave & 20.20 & 8.34 & 27.30 & 25.92 \\
\hline $\mathrm{T} 3$ & Green Manure+Ajowan & 17.26 & 21.68 & 23.22 & 37.02 \\
\hline $\mathrm{T} 4$ & Green Manure+Neem & 18.32 & 16.87 & 24.45 & 33.68 \\
\hline $\mathrm{T} 5$ & Green Manure+Tobacco & 17.73 & 19.55 & 24.27 & 34.17 \\
\hline $\mathrm{T} 6$ & $\begin{array}{c}\text { Green } \\
\text { Manure+Carbendazim }\end{array}$ & 15.76 & 28.49 & 20.67 & 43.93 \\
\hline & Overal Mean & 18.61 & & 26.02 & \\
\hline & F- test & $\mathrm{S}$ & & $\mathrm{S}$ & \\
\hline & S Ed. $( \pm)$ & 0.993 & & 1.170 & \\
\hline & $\mathrm{CD}(\mathrm{P}=\mathbf{0 . 0 5})$ & 2.1 & & 2.4 & \\
\hline
\end{tabular}

Table.4 Mycelial Growth of Alternaria porri in treatments of spice extracts

\begin{tabular}{|c|c|c|c|c|c|c|c|c|}
\hline \multicolumn{9}{|c|}{ Radial growth of three replication mean $(\mathrm{mm})$} \\
\hline \multicolumn{2}{|r|}{ Treatments } & \multicolumn{2}{|c|}{$48 \mathrm{hrs}$} & \multicolumn{2}{|c|}{$72 \mathrm{hrs}$} & \multicolumn{2}{|c|}{ 96hrs } & \multirow{2}{*}{$\begin{array}{l}\text { Mean } \\
\text { radial }\end{array}$} \\
\hline & & Radial & $\begin{array}{c}\% \\
\text { inhibition }\end{array}$ & Radial & $\begin{array}{c}\% \\
\text { inhibition }\end{array}$ & Radial & $\begin{array}{c}\text { in } \% \\
\text { hibition }\end{array}$ & \\
\hline $\mathrm{T}_{0}$ & control & 36.00 & & 45.00 & & 52.50 & & 44.50 \\
\hline $\mathrm{T}_{1}$ & Black cumin & 35.50 & 16.90 & 36.50 & 20.55 & 38.50 & 16.88 & 36.83 \\
\hline $\mathrm{T}_{2}$ & Bay Leave & 30.00 & 20.00 & 37.50 & 20.00 & 46.00 & 35.22 & 37.83 \\
\hline $\mathrm{T}_{3}$ & Ajowan & 30.00 & 23.33 & 37.50 & 12.00 & 36.30 & 13.77 & 34.60 \\
\hline $\mathrm{T}_{4}$ & Neem & 29.00 & 3.45 & 40.50 & 7.41 & 47.50 & 9.47 & 39.00 \\
\hline $\mathrm{T}_{5}$ & Tobacco & 35.00 & 1.39 & 42.00 & 18.89 & 48.00 & 26.67 & 41.67 \\
\hline \multirow{2}{*}{\multicolumn{2}{|c|}{ Overal Mean }} & 27.93 & & 34.14 & & 38.40 & & \\
\hline & & Result & & $\begin{array}{l}\text { S. Ed. } \\
( \pm)\end{array}$ & & & $\mathrm{CD} 5 \%$ & \\
\hline & Due to $h r$ & $\mathrm{~S}$ & & 2.683 & & & 5.689 & \\
\hline & Treatment & $\mathrm{S}$ & & 1.897 & & & 4.023 & \\
\hline
\end{tabular}


Fig.1 Effect of green manure amendments and spray of spices extract on purple blotch disease intensity (\%) of onion at 45 and 60 DAT

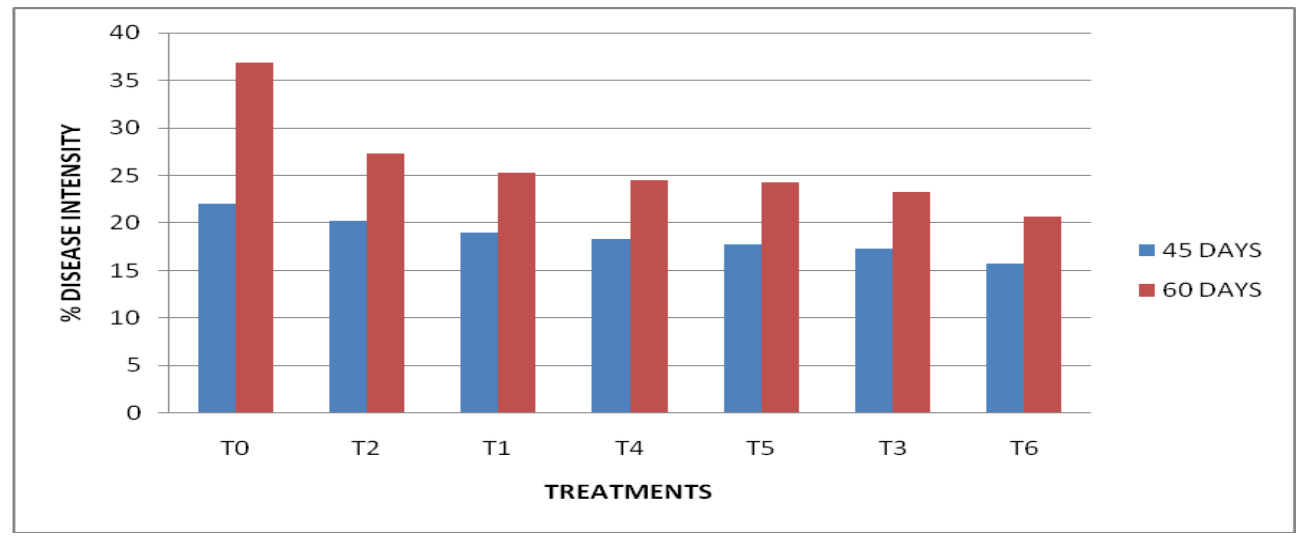

Fig.2 Effect of green manure amendments and spray of the extract of selected spices on the incidence of Alternaria porri

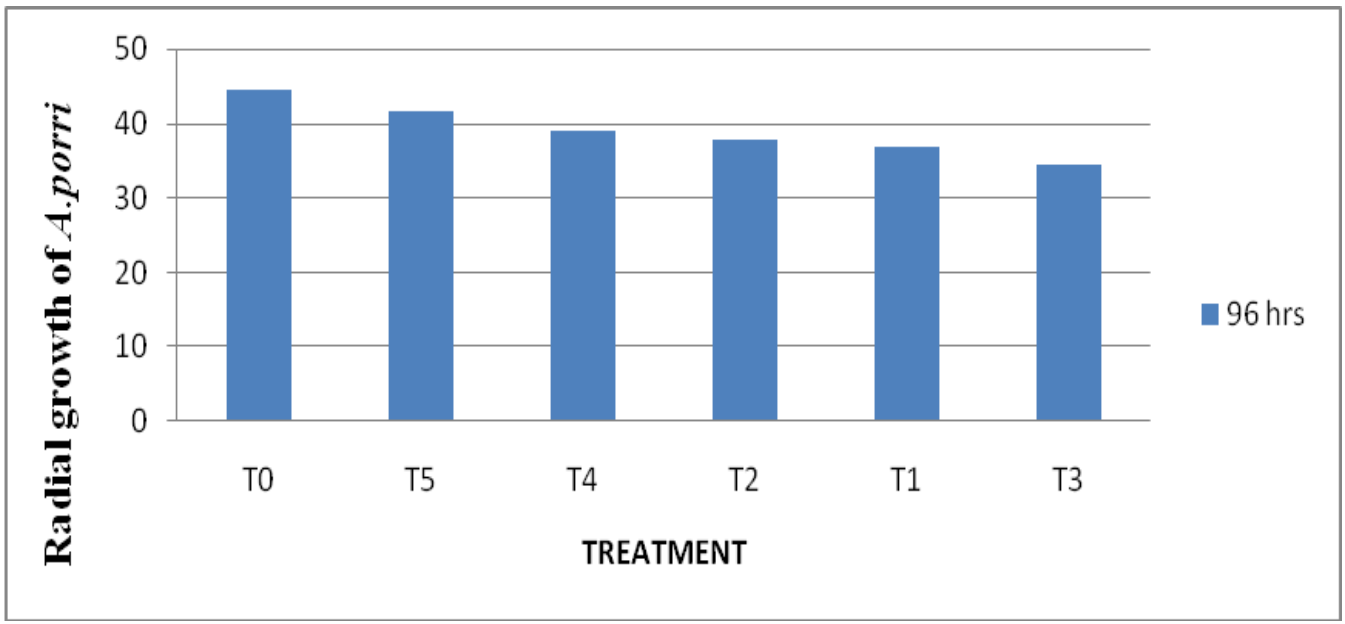

Plate.1 Symptoms of purpleblotch of onion

Conidia of Alternaria porri
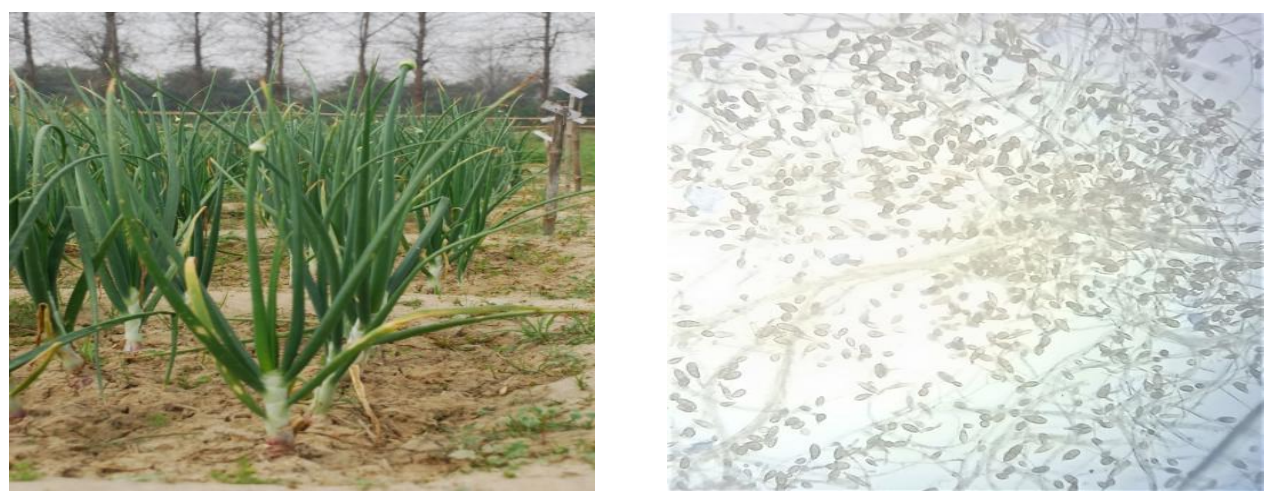
Plate.4.5 Mycelial growth of Alternaria porri in treatments of spices extracts

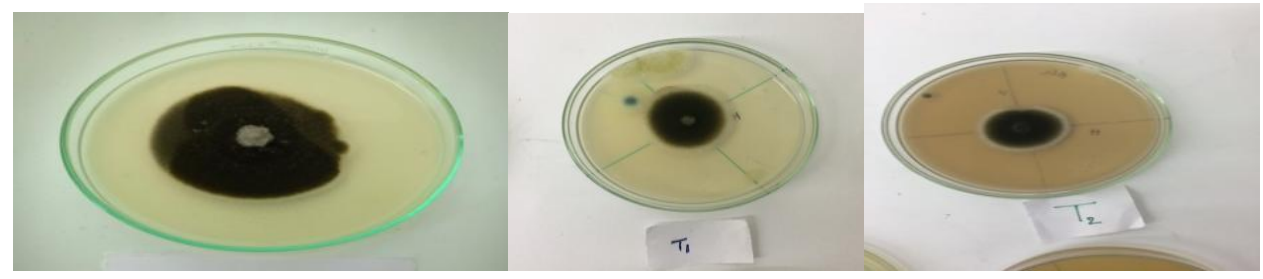

A. $\mathrm{T}_{0} \cdot$ Control (un treated)

B.T 1 .Black cumin Seeds@10\%C. T2.Bay Leaf @ 10\%

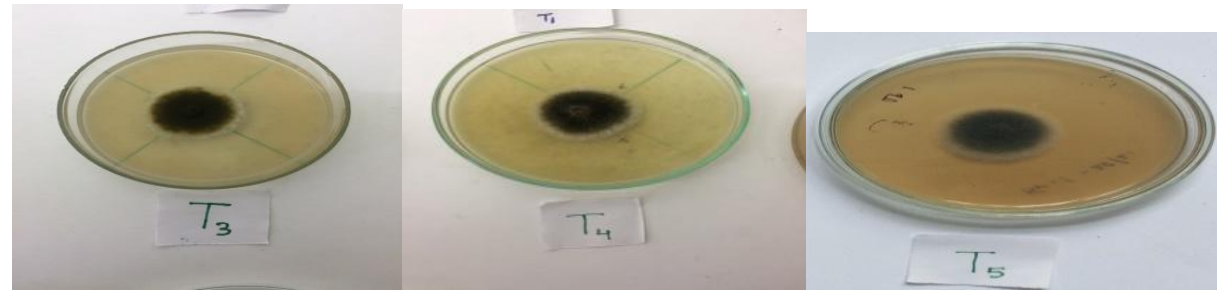

D. $T_{3}$.Ajowan Seeds @ 10\%

E.T4.Neem :Leave@ @ 10\%

F.T 5. Tobacco Leave@10\%

The exploitation of plant products for the management of plant diseases have achieved greater significance in recent times due to is readily available nature, antimicrobial activity, easy biodegradability, nonphytotoxicity, besides inducing resistance in host.in this study, among the five leaves extracts tested in vitro on Alternaria porri. Tobacco and Ajowan leaf were highly inhibitory to the mycelial growth and spore germination of Alternaria porri. In earlier, several research workers have demonstrated that some plants posse's antifungal activity against several plant diseases (Wilson et al, 1997 and Al-Mughrabi et al., 2001). From the finding of earlier work it is assumed in the present study the antifungal activity of Tobacco might reduce the growth of Alternaria porri.

From the present study, It is concluded that carbendizim @50\% WP 2100g/h was found most effective in managing the purple blotch of onion in field condition. Out of five spices maximum inhibition percentage showed the treatment is tobacco $(41.67 \%)$ and minimum inhibition percentage is Ajowan (34.60\%) percentage of A.porri mycelial growth at $10 \%$ of the respect spices in lab condition. Using of green manure amendments and spray of spice extract in the field would be considered as it is beneficial and eco-friendly. However, the present study was limited to one crop season under Prayagraj conditions, therefore, to substantiate the present result more trials are needed for 2-3 seasons for further recommendations.

\section{References}

Akash, Verma. and Sobita, Simon., (2013). Efficacy of indigenous products and carbendazim on alternaria Blight [(Alternaria lini) dey] of linseed (Linum usitatissimum 1.)

Al-Mughrabi, K.I., Abujai, T.A., Anfoka, G.H., Shahrour, W. (2001). Antifungal activity of olive cake extracts. Phytopathol Mediterr 40:240-244

Anonymous, (2015). NHRDF; Nashik (www.nhrdf.com)

Barnett, H.L. and B.B. Hunter (1987). Illustrated Genera of imperfect Fungi: Pub. C. New York, 218p. 
Ellis, M.B. and Holiday P. (1998). Alternaria porri (Descriptions of Fungi and Bacteria). IMI Descriptions of Fungi and Bacteria. 25: pp248.

FAO (2012). Food and agricultural commodities production. Food and Agricultural organization Statistics. $p$. 43.

Rands, R.D. (1917). The production of spores by Alternaria solani in pure culture. Phytopathology, vol(7): 316-317.

Sandhu (1981). Efficasy of bioagents and plant extract against Alternaria porri causing purple blotch of onion. Department of plant pathology, college of Agriculture V.N.M.A.U, Latur, MS.

Singh R. S. (1992). Disease of Vegetable
Crops. Oxford and IBH Publishing Co. Pvt. Ltd. second Edition, pp. 287-289.

Vinny John, Sobita Devi Simon, Amit Kumar Maurya, Abhilasha, A. Lal (2018). Survey of Purple Blotch Disease of Onion (Alternaria porri) of Allahabad District, India, Department of Plant Pathology, Sam Higginbottom University of Agriculture, Technology and Sciences, Allahabad (U.P.). 23197706 Volume 7 Number 10 (2018)

Wilson, C.L., Solar J.M., Ghaouth, A. Wisiniewski, ME. (1997). Rapid evaluation of plant extracts and essential oils for antifungal activity against Botryis cinera.

\section{How to cite this article:}

Rama Krishnam Raju, B. V. and Sobita Simon. 2020. Effect of Green Manure Amendments and Spray of Spices Extract on Purple Blotch Disease Intensity of Onion (Allium cepa L). Int.J.Curr.Microbiol.App.Sci. 9(12): 1903-1911. doi: https://doi.org/10.20546/ijcmas.2020.912.226 